\title{
Short communication: Prediction of hyperketonemia in dairy cows in early lactation using on-farm cow data and net energy intake by partial least square discriminant analysis
}

\author{
Wei Xu, ${ }^{1,2} \oplus$ Edoardo Saccenti, ${ }^{3}$ Jacques Vervoort, ${ }^{2} \odot$ Bas Kemp, ${ }^{1}{ }^{\oplus}$ Rupert M. Bruckmaier, ${ }^{4} \odot$ \\ and Ariette T. M. van Knegsel ${ }^{1 *}$ (i) \\ ${ }^{1}$ Adaptation Physiology group, Department of Animal Sciences, Wageningen University and Research, PO Box 338, 6700 AH, \\ Wageningen, the Netherlands \\ ${ }^{2}$ Laboratory of Biochemistry, Wageningen University and Research, PO Box 338, $6700 \mathrm{AH}$, Wageningen, the Netherlands \\ ${ }^{3}$ Laboratory of Systems and Synthetic Biology, Wageningen University and Research, Stippeneng 4, 6708 WE, Wageningen, the Netherlands \\ ${ }^{4}$ Veterinary Physiology, Vetsuisse Faculty, University of Bern, Bremgartenstrasse 109a, CH-3001, Bern, Switzerland
}

\section{ABSTRACT}

The objectives of this study were (1) to evaluate if hyperketonemia in dairy cows (defined as plasma $\beta$-hydroxybutyrate $\geq 1.0 \mathrm{mmol} / \mathrm{L}$ ) can be predicted using on-farm cow data either in current or previous lactation week, and (2) to study if adding individual net energy intake (NEI) can improve the predictive ability of the model. Plasma $\beta$-hydroxybutyrate concentration, on-farm cow data (milk yield, percentage of fat, protein and lactose, fat- and protein-corrected milk yield, body weight, body weight change, dry period length, parity, and somatic cell count), and NEI of 424 individual cows were available weekly through lactation wk 1 to 5 postpartum. To predict hyperketonemia in dairy cows, models were first trained by partial least square discriminant analysis, using on-farm cow data in the same or previous lactation week. Second, NEI was included in models to evaluate the improvement of the predictability of the models. Through leave-one trial-out cross-validation, models were evaluated by accuracy (the ratio of the sum of true positive and true negative), sensitivity $(68.2 \%$ to $84.9 \%)$, specificity $(61.5 \%$ to $98.7 \%)$, positive predictive value ( $57.7 \%$ to $98.7 \%)$, and negative predictive value $(66.2 \%$ to $86.1 \%)$ to predict hyperketonemia of dairy cows. Through lactation wk 1 to 5 , the accuracy to predict hyperketonemia using data in the same week was $64.4 \%$ to $85.5 \%$ (on-farm cow data only), $66.1 \%$ to $87.0 \%$ (model including NEI), and using data in the previous week was $58.5 \%$ to $82.0 \%$ (on-farm cow data only), $59.7 \%$ to $85.1 \%$ (model including NEI). An improvement of the accuracy of the model due to including NEI ranged among lactation weeks from $1.0 \%$ to $4.4 \%$ when using data in the same

Received July 18, 2019.

Accepted March 16, 2020.

*Corresponding author: ariette.vanknegsel@wur.nl lactation week and $0.2 \%$ to $6.6 \%$ when using data in the previous lactation week. In conclusion, trained models via partial least square discriminant analysis have potential to predict hyperketonemia in dairy cows not only using data in the current lactation week, but also using data in the previous lactation week. Net energy intake can improve the accuracy of the model, but only to a limited extent. Besides NEI, body weight, body weight change, milk fat, and protein content were important variables to predict hyperketonemia, but their rank of importance differed across lactation weeks.

Key words: partial least square discriminant analysis, metabolic status, subclinical ketosis

\section{Short Communication}

In early lactation, dairy cows typically have a negative energy balance, which has been related to metabolic disorders such as hyperketonemia (Grummer, 1993; Duffield et al., 2009). Hyperketonemia is defined as an increased concentration of plasma BHB. Commonly used thresholds for hyperketonemia are plasma concentration of BHB $\geq 1.0$ to $\geq 1.4 \mathrm{mmol} / \mathrm{L}$ in dairy cows (Walsh et al., 2007; Duffield et al., 2009). The incidence of hyperketonemia is especially high (up to $45.7 \%$ ) in the first weeks after calving (McArt et al., 2013). Hyperketonemia is related to an increased risk of disorders in peripartum period, such as subclinical and clinical ketosis (Geishauser et al., 2000; Duffield et al., 2009), left-displaced abomasum (Geishauser et al., 1997), and decreased reproductive performance (Walsh et al., 2007). An annual loss for subclinical ketosis, clinical ketosis, left-displaced abomasum, and decreased reproductive performance ranges from $£ 50$ to $£ 280$ per cow (Kossaibati and Esslemont, 1997). Reliable assessment of hyperketonemia could thus diagnose cows that are prone to metabolic disorders, but without clinical signs yet. Urine or milk ketone tests have been applied 
as cow-side tests to diagnose hyperketonemia in dairy cows on farms (Nielen et al., 1994). In addition, plasma BHB has been estimated using milk fat-to-protein ratio (Duffield et al., 1997), milk metabolites (Klein et al., 2012), and Fourier-transform infrared spectroscopy based on milk samples (van Knegsel et al., 2010; Bonfatti et al., 2019; Luke et al., 2019; Renaud et al., 2019). Alternatively, increasing number of variables are available on-farm and can be hypothesized of value to estimate hyperketonemia in dairy cows. In addition, mostly plasma BHB was estimated using data in the same lactation week, however, not using data from previous lactation week. To our knowledge, only Ehret et al. (2015) predicted milk BHB based on data in the previous lactation week, using milk production traits, and genomic and metabolic information. A reliable and early prediction of hyperketonemia in cows could assist in cow management and potentially reduce the risk for clinical and subclinical metabolic disorders. It could be expected that the prediction of hyperketonemia in cows using data in the previous lactation week will have a lower performance than using data in the same lactation week (Ehret et al., 2015).

In dairy cows, partial least square discriminant analysis (PLS-DA) has been used to analyze data with highly-correlated variables, such as metabolomics data (Sun et al., 2014; Kenéz et al., 2016) and Fourier-transform infrared spectroscopy (Valenti et al., 2013; Grelet et al., 2019). It can be hypothesized that hyperketonemia could also be predicted with PLS-DA using onfarm cow data. In fact, it is known that several on-farm cow data, such as milk yield (Lean et al., 1992), milk fat and protein percent (Duffield et al., 1997), and BW (Bernabucci et al., 2005) are related to plasma BHB, or risk for clinical and subclinical ketosis. Moreover, the number of commercial farms collecting information on net energy intake (NEI) of individual cows is slowly increasing, which would facilitate inclusion of NEI in the on-farm cow data set to predict hyperketonemia. The correlation among different on-farm cow variables, such as milk yield, milk fat, and protein, results in intricate dependencies among explanatory variables when used together in the same model (Wilmink, 1987; Xu et al., 2018). Further, it is difficult to find a specific parametric function (e.g., linear, quadratic, and so on) with conventional statistic methods. In this context, PLS model have been introduced to deal with data sets with a high degree of among correlation among predictor variables, situations where classical models fail (Wold et al., 2001). We hypothesize that hyperketonemia in dairy cows can be predicted using on-farm cow data and NEI in early lactation using PLS-DA. Objectives of this study were (1) to evaluate if hyperketonemia in dairy cows can be predicted using on-farm cow data either in the same or previous lactation week, and (2) to study if adding individual NEI can improve the predictive ability of the model.

The concentration of plasma BHB, on-farm cow data, and NEI of 424 cows originate from study I (van Knegsel et al., 2007), study II (van Knegsel et al., 2014; Chen et al., 2016), and study III (van Hoeij et al., 2017). In study II, data were collected from the same dairy cows during 2 consecutive lactations, first lactation was reported by van Knegsel et al. (2014), and second lactation was reported by Chen et al. (2016). Experimental protocols were approved by the Institutional Animal Care and Use Committee of Wageningen University. Briefly, plasma and milk samples were collected weekly. The concentration of plasma BHB was measured with kit no. RB1007 (Randox Laboratories, Ibach, Switzerland), as previously described by Graber et al. (2012). On-farm cow data included dry period length (d); parity; BW (kg); weekly BW change $(\mathrm{kg} /$ wk, BW in current week minus BW in the previous week); milk yield $(\mathrm{kg} / \mathrm{d})$; the percentage of fat, protein, and lactose; fat- and protein-corrected milk production $(\mathrm{kg} / \mathrm{d})$; and SCC (cells $/ \mathrm{mL})$. Net energy intake $(\mathrm{kJ} /$ $\mathrm{kg}^{0.75}$ ) was calculated by dietary net energy concentration and feed intake of individual cows. Of all 424 individual cows, the number of cows with complete records in each lactation week is presented in Table 1.

In the current study, due to the better metabolic status of dairy cows with shortened or omitted dry period (Chen et al., 2016), a relatively low threshold (BHB $\geq$ $1.0 \mathrm{mmol} / \mathrm{L}$ ) was used to define hyperketonemia. Hyperketonemia in dairy cows was predicted by PLS-DA using on-farm cow farm cow data and NEI. Briefly, on-farm cow data and on-farm cow data combined with NEI, either in the same lactation week or in the previous lactation week, were used as predictor variables ( $X$ matrix), whereas if dairy cows had hyperketonemia [defined as plasma BHB $\geq 1.0 \mathrm{mmol} / \mathrm{L}$ (Whitaker et al., 1983; Seifi et al., 2011)] was used, or not, as the target variable in classification $(Y)$. Predictor variables in training and testing data set were centered and scaled to unit variance after split in leave-one trial-out crossvalidation, which used 2 of 3 studies as the training data set and the remaining study as the testing data set. A large proportion of the cows had a plasma BHB $<1.0 \mathrm{mmol} / \mathrm{L}$ ( $81.4 \%$ to $84.5 \%$ among lactation weeks), which would give too much weight to cows without hyperketonemia when training models, and would impair the accuracy when predicting hyperketonemia in dairy cows. Therefore, data were re-sampled to obtain a reduced and balanced data set (Grelet et al., 2016). Cows without hyperketonemia were randomly sampled to obtain a data set where the proportion of cows without hyperketonemia was the same as the proportion 
of cows with hyperketonemia. In addition, to avoid an overoptimistic accuracy caused by repeated use of the same cow (Wang and Bovenhuis, 2019) in different studies, cows were only present once either in the training data set, or in the testing data set, within the same week. After 5,000 times cross-validation, the predictive ability of models was evaluated by the accuracy (the ratio of the sum of true positive and true negative), sensitivity, specificity, positive predictive value (PPV), and negative predictive value (NPV). In the PLS-DA model, variable importance in projection (VIP) score was used to quantify the contribution of each variable (Wold et al., 2001). Data pre-processing, including log-transformation and scaling, model training with PLS-DA, and the component number in PLS-DA (determined by maximum accuracy) were programed in Python (version 3.6) using modules "pandas," "numpy," and "sklearn." Figures were plotted in R (version 3.3.3, R Foundation for Statistical Computing, Vienna, Austria) with package "ggplot2."

From lactation wk 1 to 5 , averaged milk production (SD in parentheses) was 25.5 (8.9), 33.4 (7.7), 37.2 (7.9), 39.2 (8.3), and $39.2(8.3) \mathrm{kg} / \mathrm{d}$, respectively. Plasma BHB concentration (SD) was $0.70(0.30), 0.83$ (0.62), $0.84(0.54), 0.84(0.71)$, and $0.84(0.72) \mathrm{mmol} / \mathrm{L}$ for lactation wk 1 to 5 , respectively. Incidence of hyperketonemia was $12.4 \%, 20.7 \%, 20.5 \%, 17.4 \%$, and $15.8 \%$ for lactation wk 1 to 5 , respectively.

When applying on-farm cow data in the same week to predict hyperketonemia in cows, the model predicted hyperketonemia best in wk 3 (maximum accuracy 85.5 $\pm 5.8 \%)$, followed by wk $2(82.0 \pm 5.5 \%)$, wk $4(81.6$ $\pm 6.2 \%)$, wk $5(79.5 \pm 7.5 \%)$, and wk $1(79.4 \pm 9.1 \%$; Figure 1A). Through lactation wk 1 to 5 , sensitivity ranged from $68.2 \%$ to $84.9 \%$, specificity from $61.5 \%$ to $98.7 \%$, PPV from $57.7 \%$ to $98.7 \%$, and NPV from $66.2 \%$ to $86.1 \%$ (Supplemental Table S1; https://doi $. \operatorname{org} / 10.3168 /$ jds.2019-17284).
When applying on-farm cow data in the previous week to predict hyperketonemia in cows, the model predicted hyperketonemia best in wk 4 (maximum accuracy $82.0 \pm 6.3 \%)$, followed by wk $3(81.4 \pm 5.8 \%)$, wk $5(80.4 \pm 6.9 \%)$, and wk $2(65.1 \pm 7.7 \%$; Figure 1B). Through lactation wk 2 to 5 , sensitivity ranged from $56.3 \%$ to $82.8 \%$, specificity from $51.4 \%$ to $89.4 \%$, PPV from $51.1 \%$ to $90.5 \%$, and NPV from $54.2 \%$ to $84.5 \%$ (Supplemental Table S1; https://doi.org/10 $.3168 /$ jds.2019-17284).

The ability of model to predict hyperketonemia in dairy cows differed across lactation weeks. Models usually have a better performance to predict cows in study III than cows in study I and II. Prediction of hyperketonemia in dairy cows in wk 3 is better than the prediction in other weeks, independent if data in the same or previous lactation week are used. Dairy cows usually have a greater incidence of hyperketonemia in lactation wk 2 and 3 (Geishauser et al., 2000) in early lactation. In our results, the incidence of hyperketonemia in lactation wk $2(20.5 \%)$ and $3(20.7 \%)$ is greater than the incidence in wk 1, 4, and 5 (range $12.4 \%$ to $17.4 \%$ ). The high incidence of hyperketonemia in wk 3 , compared with other weeks, indicates dairy cows are prone to hyperketonemia, which could be related to the maximum accuracy $(85.5 \%)$ to predict hyperketonemia in wk 3 compared with other weeks. The prediction using data in lactation wk 1 , however, was worse than in other weeks, which could be related to the high variation of variables related to milk production at start of lactation (Drackley, 1999). Generally, the prediction of hyperketonemia in dairy cows was better using data in the same week than data in the previous week. In principle, it seems logical that on-farm cow data in the same week give a more accurate prediction because these data reflect the altered metabolic status of a cow real-time. Nevertheless, although metabolic status of cows vary highly across consecutive weeks during

Table 1. Number of cows with complete records (on-farm cow data and individual net energy intake) in lactation wk 1 to 5 in the prediction of hyperketonemia using data in the same (wk $n$ to wk $n$ ) and previous (wk $n$ to wk $n+1)$ lactation week ${ }^{1}$

Completed records in each lactation week

\begin{tabular}{lccccc}
\cline { 2 - 5 } Study $^{2}$ & wk 1 to wk $1 / 2^{3}$ & wk 2 to wk $2 / 3$ & wk 3 to wk $3 / 4$ & wk 4 to wk $4 / 5$ & wk 5 to wk 5 \\
\hline Study I & $69(93) / 69(93)$ & $72(97) / 72(97)$ & $72(97) / 72(97)$ & $72(97) / 71(96)$ & $16(97)$ \\
Study II & $114(50) / 119(52)$ & $114(50) / 115(50)$ & $164(72) / 164(72)$ & $168(74) / 72(56)$ & $168(74)$ \\
Study III & $91(75) / 111(91)$ & $111(91) / 111(91)$ & $121(99) / 121(99)$ & $121(99) / 120(99)$ & $361(99)$ \\
Total & $274(65) / 299(71)$ & $297(70) / 298(71)$ & $357(84) / 357(84)$ & $361(85) / 354(83)$ & $361(85)$ \\
\hline
\end{tabular}

${ }^{1}$ The hyperketonemia in dairy cows in lactation wk 1 was not predicted by data in the previous week.

${ }^{2}$ The experimental design, dry period length, and diet in study I were described by van Knegsel et al. (2007), in study II were decribed by van Knegsel et al. (2014) and Chen et al. (2016), and in study III were described by van Hoeij et al. (2017).

"Wk $\mathrm{n}$ to wk $\mathrm{n} / \mathrm{n}+1$ " represents number of cows used to predict hyperketonemia in dairy cows in wk $\mathrm{n}$ using data in the same week (wk $\mathrm{n}$ to wk $\mathrm{n}$ ) or in the previous week (wk n to wk $\mathrm{n}+1)$. "69(93)/69(93)" indicates that the on-farm cow data of 69 (93\% in records of study I) cows are used to predict hyperketonemia in lactation wk 1 , and 69 (93\% in records of study I) cows are used to predict hyperketonemia in lactation wk 2. 

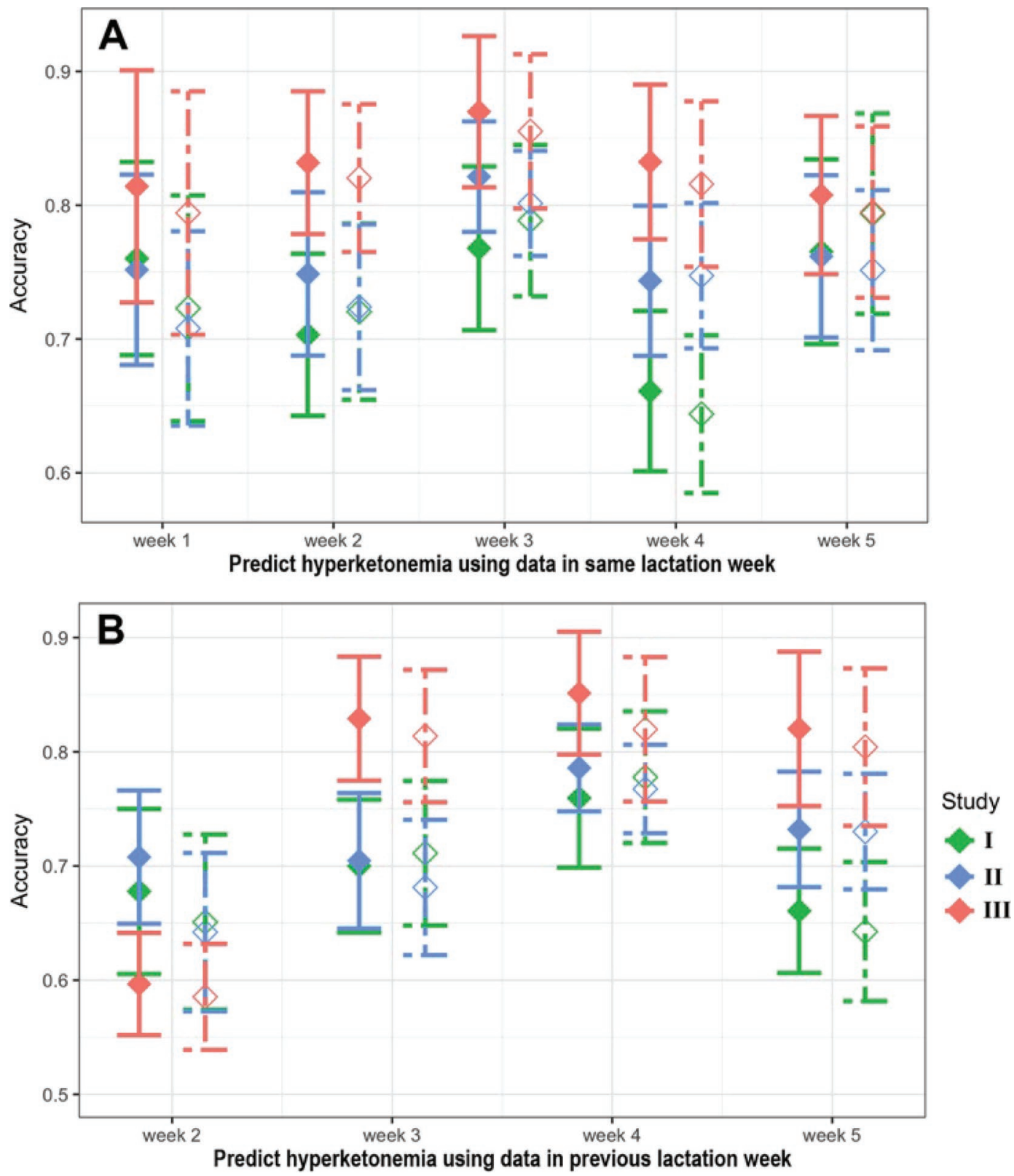

Figure 1. Accuracy of partial least squares discriminant analysis to predict hyperketonemia in dairy cows using on-farm cow data (FD; solid line) and using FD combined with net energy intake (NEI; dotted line) either in the same lactation week (A) or in the previous lactation week (B). Error bars represent SD of accuracy.

the first weeks of lactation (Oikonomou et al., 2008), predictive performance based on data in the previous week is reasonably good, compared with data in the same week.

When adding NEI in the same week to predict hyperketonemia in cows in lactation wk 1 to 5 , model accuracy improved $(P<0.05)$ with maximum $4.4 \%$, $2.5 \%, 2.0 \%, 1.7 \%$, and $1.0 \%$, respectively. When adding NEI in the previous week to predict hyperketonemia in cows in lactation wk 2 to 5, model accuracy improved
$(P<0.05)$ with maximum $6.6 \%, 2.3 \%, 3.2 \%$, and $1.8 \%$, respectively.

Due to the higher performance of using study III as testing data set, the VIP scores of PLS-DA models to predict hyperketonemia of cows in study III are presented in Figure 2. The VIP scores of PLS-DA models to predict hyperketonemia of cows in study I and study II are presented in Supplemental Figure S1 (https:// doi.org/10.3168/jds.2019-17284). Results indicate the contribution of each variable to predict hyperketonemia 
with and without NEI. Generally, across lactation wk 1 until 5, BW, BW change, milk fat and protein yield, and milk fat and protein percentage are among the best variables to predict hyperketonemia. When NEI was added to the models to predict hyperketonemia, NEI had the relative high contribution among all variables to contribute to the prediction of hyperketonemia, although the increase in model accuracy was limited. Moreover, BW (Halachmi et al., 2004), BW change (Staples et al., 1990), and milk fat and protein yield or percentage (Hurtaud et al., 2000) are all related to NEI in dairy cows. This implies that part of the effect of NEI was already accounted for in the model using onfarm cow data only and explains possibly why the rela- tive increase in accuracy when adding NEI is marginal. Further study could consider the variance of important variables not only to predict hyperketonemia, but also to predict reproductive performance (Hempstalk et al., 2015), mastitis (Sun et al., 2010), and milk yield (Gianola et al., 2011) with machine learning techniques in the context of precision dairy farming.

In this study, hyperketonemia in dairy cows was predicted using on-farm cow data and on-farm cow data combined with NEI in early lactation by PLSDA. Although only PLS-DA had been applied in our study, it does not mean PLS-DA is the best algorithm in practice. To find out the best method for predicting hyperketonemia of dairy cows, more advanced
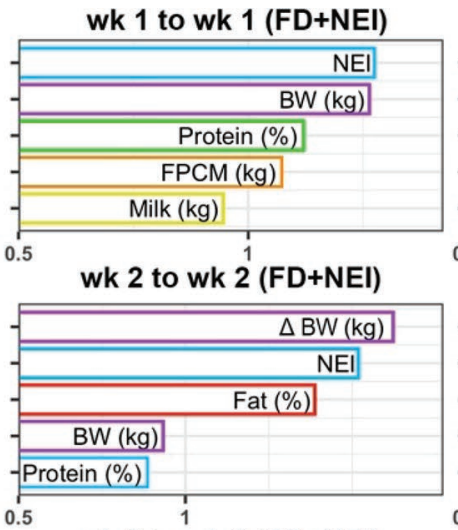

wk 3 to wk 3 (FD+NEI)



wk 4 to wk 4 (FD+NEI)
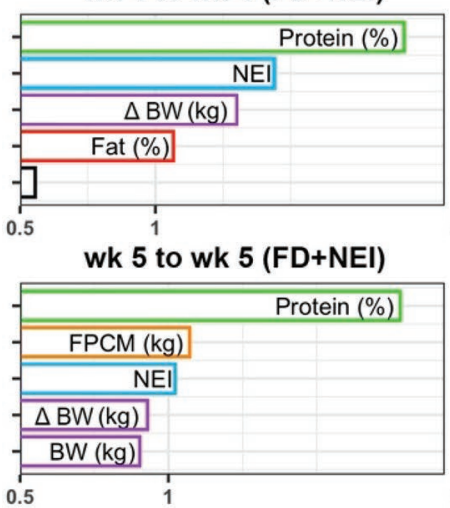

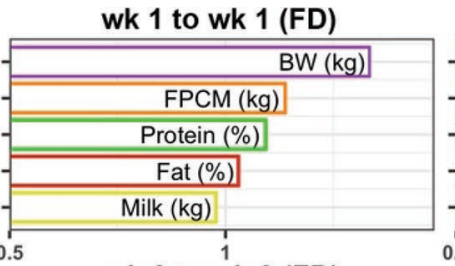

wk 1 to wk 2 (FD+NEI)



wk 2 to wk 3 (FD+NEI)


$0.5 \quad$ wk 4 to wk 4 (FD)



wk 5 to wk 5 (FD)





$0.5 \quad$ wk 3 to wk 4 (FD+NEI)

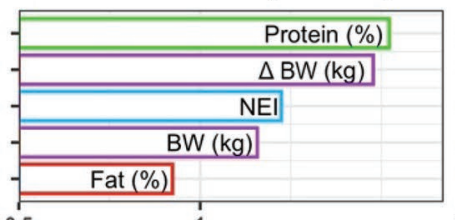

$0.5 \quad$ wk 4 to ${ }^{1}$ wk 5 (FD+NEI)
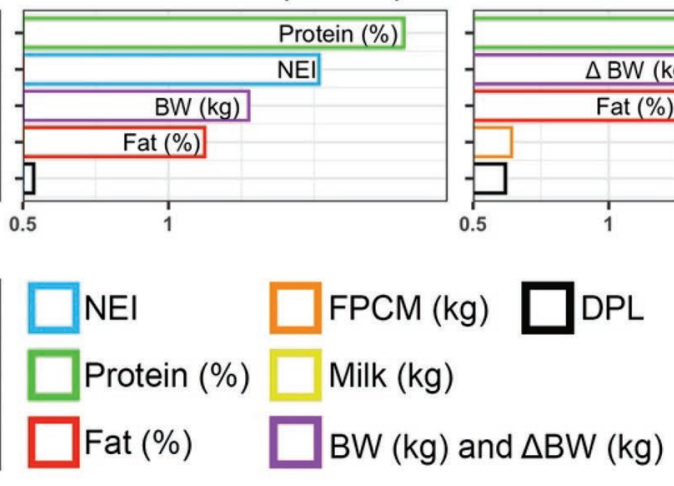

wk 1 to wk 2 (FD)



wk 2 to wk 3 (FD)



wk 3 to wk 4 (FD)

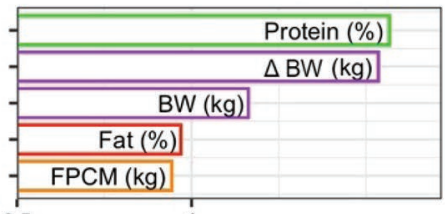

wk 4 to wk 5 (FD)

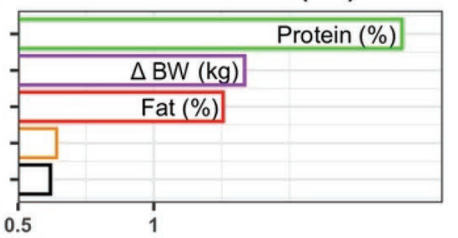

Figure 2. The variable importance in projection (VIP) scores (x-axis) in the first principal component calculated by partial least squares discriminant analysis to predict hyperketonemia in dairy cows in study III with on-farm cow data (FD) only and FD combined with net energy intake (NEI). The x label in each subplot follows the format "wk $n$ to wk $m$ (FD or FD + NEI)," which is presented as "data of week $n$ (wk $n$ ) to predict hyperketonemia in dairy cows in week $m($ wk $m)$." FPCM = fat- and protein-corrected milk production; $\Delta \mathrm{BW}=\mathrm{BW}$ change; DPL $=$ dry period length; Milk = milk yield. 
algorithms could be evaluated, such as random forest, artificial neural networks, and support vector machine. In our previous study, random forest outperformed the other tested algorithms, including artificial neural networks and support vector machine, to predict metabolic status of dairy cows in early lactation (Xu et al., 2019). The accuracy of random forest, artificial neural networks, and support vector machine to predict hyperketonemia, however, was marginally lower than PLSDA in our preliminary study (Supplemental Table S2; https://doi.org/10.3168/jds.2019-17284). Algorithms including random forest and PLS-DA also have been applied in other studies of dairy cows to predict milk yield (Gianola et al., 2011), reproductive performance (Hempstalk et al., 2015), and metabolic status (Xu et al., 2019).

Due to the low incidence of dairy cows with hyperketonemia (12.4\%-20.7\% through lactation wk 1 to 5 ), different strategies were considered to improve the model performance (Aiken et al., 2019), as presented in Supplemental Table S3 (https://doi.org/10.3168/jds .2019-17284). Models using a data set without sampling and using a data set sampled with two-thirds of cows without hyperketonemia generally had greater accuracy than model using a data set sampled with one-half of cows without hyperketonemia. The marginal difference of sensitivity, specificity, PPV, and NPV among these 3 strategies indicated that an balanced or unbalanced data set did not compromise these values. Therefore, we would suggest to use a balanced data set $(50 \%$ vs. $50 \%)$ to maximize the accuracy range $(50 \%-100 \%)$ of a model trained with different data or algorithms.

In conclusion, hyperketonemia in dairy cows can be predicted using on-farm cow data in both the same and previous lactation week, although with some reduction in accuracy when using data in the previous lactation week. Adding individual NEI improved the predictive ability of model with extra $0.2 \%$ to $6.6 \%$ accuracy. Besides NEI, BW, BW change, milk fat, and milk protein play important roles to predict hyperketonemia in dairy cows.

\section{ACKNOWLEDGMENTS}

The authors thank the China Scholarship Council (Beijing, China) for financial support of the PhD study of the first author. The authors thank the staff of Dairy Campus (Lelystad, the Netherlands) and Schothorst Feed Research dairy herd (Lelystad, the Netherlands), Renny van Hoeij (Wageningen University and Research, Wageningen, the Netherlands), and Gerrit Remmelink (Wageningen Livestock Research, Wageningen, the Netherlands) for their assistance during the experiments. The authors have no conflicts of interest.

\section{REFERENCES}

Aiken, V. C. F., J. R. R. Dórea, J. S. Acedo, F. G. de Sousa, F. G. Dias, and G. J. de Magalhães Rosa. 2019. Record linkage for farmlevel data analytics: Comparison of deterministic, stochastic and machine learning methods. Comput. Electron. Agric. 163:104857. https://doi.org/10.1016/j.compag.2019.104857.

Bernabucci, U., B. Ronchi, N. Lacetera, and A. Nardone. 2005. Influence of body condition score on relationships between metabolic status and oxidative stress in periparturient dairy cows. J. Dairy Sci. 88:2017-2026. https://doi.org/10.3168/jds.S0022 $-0302(05) 72878-2$.

Bonfatti, V., S. A. Turner, B. Kuhn-Sherlock, T. D. W. Luke, P. N. Ho, C. V. C. Phyn, and J. E. Pryce. 2019. Prediction of blood $\beta$-hydroxybutyrate content and occurrence of hyperketonemia in early-lactation, pasture-grazed dairy cows using milk infrared spectra. J. Dairy Sci. 102:6466-6476. https://doi.org/10.3168/jds .2018-15988.

Chen, J., G. Remmelink, J. J. Gross, R. Bruckmaier, B. Kemp, and A. van Knegsel. 2016. Effects of dry period length and dietary energy source on milk yield, energy balance, and metabolic status of dairy cows over 2 consecutive years: Effects in the second year. J. Dairy Sci. 99:4826-4838. https://doi.org/10.3168/jds.2015-10742.

Drackley, J. K. 1999. Biology of dairy cows during the transition period: The final frontier? J. Dairy Sci. 82:2259-2273. https://doi .org/10.3168/jds.S0022-0302(99)75474-3.

Duffield, T. F., D. F. Kelton, K. E. Leslie, K. D. Lissemore, and J. H. Lumsden. 1997. Use of test day milk fat and milk protein to detect subclinical ketosis in dairy cattle in Ontario. Can. Vet. J. 38:713-718.

Duffield, T. F., K. Lissemore, B. McBride, and K. Leslie. 2009. Impact of hyperketonemia in early lactation dairy cows on health and production. J. Dairy Sci. 92:571-580. https://doi.org/10.3168/jds .2008-1507.

Ehret, A., D. Hochstuhl, N. Krattenmacher, J. Tetens, M. S. Klein, W. Gronwald, and G. Thaller. 2015. Short communication: Use of genomic and metabolic information as well as milk performance records for prediction of subclinical ketosis risk via artificial neural networks. J. Dairy Sci. 98:322-329. https://doi.org/10.3168/ jds.2014-8602.

Geishauser, T., K. Leslie, T. Duffield, and V. Edge. 1997. An evaluation of milk ketone tests for the prediction of left displaced abomasum in dairy cows. J. Dairy Sci. 80:3188-3192. https://doi.org/10 .3168/jds.S0022-0302(97)76291-X.

Geishauser, T., K. Leslie, J. Tenhag, and A. Bashiri. 2000. Evaluation of eight cow-side ketone tests in milk for detection of subclinical ketosis in dairy cows. J. Dairy Sci. 83:296-299. https://doi.org/10 .3168/jds.S0022-0302(00)74877-6.

Gianola, D., H. Okut, K. A. Weigel, and G. J. Rosa. 2011. Predicting complex quantitative traits with Bayesian neural networks: A case study with Jersey cows and wheat. BMC Genet. 12:87. https://doi .org/10.1186/1471-2156-12-87.

Graber, M., S. Kohler, A. Müller, K. Burgermeister, T. Kaufmann, R. Bruckmaier, and H. van Dorland. 2012. Identification of plasma and hepatic parameters related to metabolic robustness in dairy cows. J. Anim. Physiol. Anim. Nutr. (Berl.) 96:75-84. https://doi .org/10.1111/j.1439-0396.2010.01124.x.

Grelet, C., C. Bastin, M. Gelé, J. B. Davière, M. Johan, A. Werner, R. Reding, J. A. Fernandez Pierna, F. G. Colinet, P. Dardenne, N. Gengler, H. Soyeurt, and F. Dehareng. 2016. Development of Fourier transform mid-infrared calibrations to predict acetone, $\beta$-hydroxybutyrate, and citrate contents in bovine milk through a European dairy network. J. Dairy Sci. 99:4816-4825. https://doi .org/10.3168/jds.2015-10477.

Grelet, C., A. Vanlierde, M. Hostens, L. Foldager, M. Salavati, K. L. Ingvartsen, M. Crowe, M. T. Sorensen, E. Froidmont, C. P. Ferris, C. Marchitelli, F. Becker, T. Larsen, F. Carter, and F. Dehareng. 2019. Potential of milk mid-IR spectra to predict metabolic status of cows through blood components and an innovative clustering approach. Animal 13:649-658. https://doi.org/10.1017/ S1751731118001751. 
Grummer, R. R. 1993. Etiology of lipid-related metabolic disorders in periparturient dairy cows. J. Dairy Sci. 76:3882-3896. https://doi .org/10.3168/jds.S0022-0302(93)77729-2.

Halachmi, I., Y. Edan, U. Moallem, and E. Maltz. 2004. Predicting feed intake of the individual dairy cow. J. Dairy Sci. 87:2254-2267. https://doi.org/10.3168/jds.S0022-0302(04)70046-6.

Hempstalk, K., S. McParland, and D. Berry. 2015. Machine learning algorithms for the prediction of conception success to a given insemination in lactating dairy cows. J. Dairy Sci. 98:5262-5273. https://doi.org/10.3168/jds.2014-8984.

Hurtaud, C., S. Lemosquet, and H. Rulquin. 2000. Effect of graded duodenal infusions of glucose on yield and composition of milk from dairy cows. 2. Diets based on grass silage. J. Dairy Sci. 83:29522962. https://doi.org/10.3168/jds.S0022-0302(00)75195-2.

Kenéz, Á., S. Dänicke, U. Rolle-Kampczyk, M. von Bergen, and K. Huber. 2016. A metabolomics approach to characterize phenotypes of metabolic transition from late pregnancy to early lactation in dairy cows. Metabolomics 12:165. https://doi.org/10.1007/s11306 $-016-1112-8$

Klein, M. S., N. Buttchereit, S. P. Miemczyk, A.-K. Immervoll, C. Louis, S. Wiedemann, W. Junge, G. Thaller, P. J. Oefner, and W. Gronwald. 2012. NMR metabolomic analysis of dairy cows reveals milk glycerophosphocholine to phosphocholine ratio as prognostic biomarker for risk of ketosis. J. Proteome Res. 11:1373-1381. https://doi.org/10.1021/pr201017n.

Kossaibati, M. A., and R. Esslemont. 1997. The costs of production diseases in dairy herds in England. Vet. J. 154:41-51. https://doi .org/10.1016/S1090-0233(05)80007-3.

Lean, I. J., T. Farver, H. Troutt, M. Bruss, J. Galland, R. Baldwin, C. Holmberg, and L. Weaver. 1992. Time series cross-correlation analysis of postparturient relationships among serum metabolites and yield variables in Holstein cows. J. Dairy Sci. 75:1891-1900. https://doi.org/10.3168/jds.S0022-0302(92)77949-1.

Luke, T. D. W., S. Rochfort, W. J. Wales, V. Bonfatti, L. Marett, and J. E. Pryce. 2019. Metabolic profiling of early-lactation dairy cows using milk mid-infrared spectra. J. Dairy Sci. 102:1747-1760. https://doi.org/10.3168/jds.2018-15103.

McArt, J. A. A., D. V. Nydam, and G. R. Oetzel. 2013. Dry period and parturient predictors of early lactation hyperketonemia in dairy cattle. J. Dairy Sci. 96:198-209. https://doi.org/10.3168/ jds.2012-5681.

Nielen, M., M. Aarts, A. Jonkers, T. Wensing, and Y. H. Schukken. 1994. Evaluation of two cowside tests for the detection of subclinical ketosis in dairy cows. Can. Vet. J. 35:229-232.

Oikonomou, G., G. Valergakis, G. Arsenos, N. Roubies, and G. Banos. 2008. Genetic profile of body energy and blood metabolic traits across lactation in primiparous Holstein cows. J. Dairy Sci. 91:2814-2822. https://doi.org/10.3168/jds.2007-0965.

Renaud, D. L., D. F. Kelton, and T. F. Duffield. 2019. Short communication: Validation of a test-day milk test for $\beta$-hydroxybutyrate for identifying cows with hyperketonemia. J. Dairy Sci. 102:15891593. https://doi.org/10.3168/jds.2018-14778.

Seifi, H. A., S. J. LeBlanc, K. E. Leslie, and T. F. Duffield. 2011. Metabolic predictors of post-partum disease and culling risk in dairy cattle. Vet. J. 188:216-220. https://doi.org/10.1016/j.tvjl 2010.04.007.

Staples, C. R., W. W. Thatcher, and J. H. Clark. 1990. Relationship between ovarian activity and energy status during the early postpartum period of high producing dairy cows. J. Dairy Sci. 73:938-947. https://doi.org/10.3168/jds.S0022-0302(90)78750-4.

Sun, L. W., H. Zhang, L. Wu, S. Shu, C. Xia, C. Xu, and J. Zheng. 2014. 1H-Nuclear magnetic resonance-based plasma metabolic profiling of dairy cows with clinical and subclinical ketosis. J. Dairy Sci. 97:1552-1562. https://doi.org/10.3168/jds.2013-6757.

Sun, Z., S. Samarasinghe, and J. Jago. 2010. Detection of mastitis and its stage of progression by automatic milking systems using artifi- cial neural networks. J. Dairy Res. 77:168-175. https://doi.org/10 $.1017 /$ S0022029909990550.

Valenti, B., B. Martin, D. Andueza, C. Leroux, C. Labonne, F. Lahalle, H. Larroque, P. Brunschwig, C. Lecomte, M. Brochard, and A. Ferlay. 2013. Infrared spectroscopic methods for the discrimination of cows' milk according to the feeding system, cow breed and altitude of the dairy farm. Int. Dairy J. 32:26-32. https://doi.org/ 10.1016/j.idairyj.2013.02.014

van Hoeij, R. J., J. Dijkstra, R. M. Bruckmaier, J. J. Gross, T. J. G. M. Lam, G. J. Remmelink, B. Kemp, and A. T. M. van Knegsel. 2017. Consequences of dietary energy source and energy level on energy balance, lactogenic hormones, and lactation curve characteristics of cows after a short or omitted dry period. J. Dairy Sci. 100:8544-8564. https://doi.org/10.3168/jds.2017-12855.

van Knegsel, A. T., G. Remmelink, S. Jorjong, V. Fievez, and B. Kemp. 2014. Effect of dry period length and dietary energy source on energy balance, milk yield, and milk composition of dairy cows. J. Dairy Sci. 97:1499-1512. https://doi.org/10.3168/jds.2013-7391.

van Knegsel, A. T., H. Van den Brand, J. Dijkstra, W. Van Straalen, R. Jorritsma, S. Tamminga, and B. Kemp. 2007. Effect of glucogenic vs. lipogenic diets on energy balance, blood metabolites, and reproduction in primiparous and multiparous dairy cows in early lactation. J. Dairy Sci. 90:3397-3409. https://doi.org/10.3168/jds .2006-837.

van Knegsel, A. T., S. Van Der Drift, M. Horneman, A. De Roos, B. Kemp, and E. Graat. 2010. Ketone body concentration in milk determined by Fourier transform infrared spectroscopy: Value for the detection of hyperketonemia in dairy cows. J. Dairy Sci. 93:3065-3069. https://doi.org/10.3168/jds.2009-2847.

Walsh, R. B., J. S. Walton, D. F. Kelton, S. J. LeBlanc, K. E. Leslie, and T. F. Duffield. 2007. The Effect of subclinical ketosis in early lactation on reproductive performance of postpartum dairy cows. J. Dairy Sci. 90:2788-2796. https://doi.org/10.3168/jds.2006-560.

Wang, Q., and H. Bovenhuis. 2019. Validation strategy can result in an overoptimistic view of the ability of milk infrared spectra to predict methane emission of dairy cattle. J. Dairy Sci. 102:6288-6295. https://doi.org/10.3168/jds.2018-15684.

Whitaker, D. A., J. Kelly, and E. Smith. 1983. Subclinical ketosis and serum beta-hydroxybutyrate levels in dairy cattle. Br. Vet. J. 139:462-463. https://doi.org/10.1016/S0007-1935(17)30393-7.

Wilmink, J. 1987. Adjustment of test-day milk, fat and protein yield for age, season and stage of lactation. Livest. Prod. Sci. 16:335348. https://doi.org/10.1016/0301-6226(87)90003-0.

Wold, S., M. Sjostrom, and L. Eriksson. 2001. PLS-regression: a basic tool of chemometrics. Chemom. Intell. Lab. Syst. 58:109-130. https://doi.org/10.1016/S0169-7439(01)00155-1.

Xu, W., A. T. M. van Knegsel, J. J. M. Vervoort, R. M. Bruckmaier, R. J. van Hoeij, B. Kemp, and E. Saccenti. 2019. Prediction of metabolic status of dairy cows in early lactation with on-farm cow data and machine learning algorithms. J. Dairy Sci. 102:1018610201. https://doi.org/10.3168/jds.2018-15791.

Xu, W., J. Vervoort, E. Saccenti, R. van Hoeij, B. Kemp, and A. van Knegsel. 2018. Milk metabolomics data reveal the energy balance of individual dairy cows in early lactation. Sci. Rep. 8:15828. https: //doi.org/10.1038/s41598-018-34190-4.

\section{ORCIDS}

Wei Xu • Jacques Vervoort $\odot$ https://orcid.org/0000-0002-0091-5687 Bas Kemp 나 https://orcid.org/0000-0002-9765-9105

Rupert M. Bruckmaier (ㄴ https://orcid.org/0000-0002-9374-5890 Ariette T. M. van Knegsel @ https://orcid.org/0000-0003-1959-3363 